\title{
Neolasioptera ramicola, a new species of Cecidomyiidae (Diptera) associated with Physalis angulata (Solanaceae)
}

\author{
Valéria Cid Maia ${ }^{1}$, Marcelo Zart² \& Marcos Botton ${ }^{3}$
}

\begin{abstract}
${ }^{1}$ Museu Nacional, Quinta da Boa Vista, São Cristóvão, 20940-040 Rio de Janeiro-RJ, Brazil. maiavcid@acd.ufrj.br
${ }^{2}$ Embrapa Uva e Vinho, Rua Livramento 515, Caixa Postal 130, 95700-000 Bento Gonçalves-RS, Brazil.

${ }^{3}$ Universidade Estadual Paulista, Via de acesso Paulo Donato Castellane, s/n, 14884-900 Jaboticabal-SP, Brazil.
\end{abstract}

\begin{abstract}
Neolasioptera ramicola, a new species of Cecidomyiidae (Diptera) associated with Physalis angulata (Solanaceae). Neolasioptera ramicola Maia, a new species of Cecidomyiidae (Diptera) that induces stem galls on Physalis angulata (Solanaceae) is described and illustrated (larva, pupa, male, female and gall) based on material from Bento Gonçalves, Rio Grande do Sul, Brazil.
\end{abstract}

KEYWORDS. Physalis; Solanaceae; southern Brazil.

RESUMO. Neolasioptera ramicola, uma nova espécie de Cecidomyiidae (Diptera) associada com Physalis angulata (Solanaceae). Neolasioptera ramicola Maia, uma nova espécie de Cecidomyiidae (Diptera) que induz galhas caulinares em Physalis angulata (Solanaceae) é descrita e ilustrada (larva, pupa, male, fêmea e galha) com base em material coletado em Bento Gonçalves, Rio Grande do Sul, Brasil.

PALAVRAS-CHAVE. Physalis; Solanaceae; sul do Brasil.

Physalis angulata $\mathrm{L}$. is a plant of the Solanaceae family that had its origin in Colombia (Andes) and Brazil (Amazon and southeastern region), but is now a weed in other parts of the world. The species is commonly known in Brazil as camapum, saco-de-bode, bucho-de-rã, juá de capote, balão and Physalis. In Europe and U.S.A. the species is called cutleaf groundcherry, Hosuki in Japan and Uchuva in Colombia, which is the main producer. In southern Brazil, the crop has been cultivated in small farms, but there is little information about plant and insect pest management under these conditions (Briguenti \& Madeira, 2007).

Stem galls were observed on this plant in field conditions. The galler was identified as a new species of Neolasioptera Felt, 1908 and is described here.

\section{MATERIALAND METHODS}

Samples of galls were collected in Faria Lemos (29 $06^{\prime} 40^{\prime \prime}$ $\mathrm{S}, 51^{\circ} 36^{\prime} 01^{\prime \prime} \mathrm{W}$ and $430 \mathrm{~m}$ altitude) district of Bento Gonçalves, in the state of Rio Grande do Sul, Brazil and taken to the laboratory. Larvae were obtained by dissection of some galls under a stereoscopic microscope. Pupal exuviae were directly removed from the galls. Adults were obtained by keeping samples of galls in plastic containers $(0.25 \mathrm{~m}$ diameter for 0.30 $\mathrm{m}$ of height) covered cheesecloth fastened with rubber band. The pots were inspected daily to observe adult emergence. Immatures stage and adults were fixed in $70 \%$ ethanol and then mounted on slides, following the methodology described by Gagné (1994). The field work and rearing were done by M. Zart and M. Bottom; the new species was described by V.C. Maia. Morphological terminology for adults and immature stages follows that of Gagné (1994). All specimens (including types) are deposited in the Diptera collection of Museu Nacional, Rio de Janeiro (MNRJ).

\section{Neolasioptera ramicola Maia, sp. nov.}

(Figs. 1-20)

Adult. Body length: 1.7-2.4 mm in male ( $\mathrm{n}=5) ; 2.1-2.5 \mathrm{~mm}$ in female (from head until abdominal segment 7$)(n=5)$.

Head (Fig. 1): eye facets hexagonal; vertex with facets; antenna: scape obconic, about $0.05 \mathrm{~mm}$ in length in both sexes $(n=8)$; pedicel globose $0.035-0.05 \mathrm{~mm}$ in length in both sexes $(n=8)$; number of flagellomeres: $12-13$ in male; $15-18$ in female; flagellomeres 1 and 2 connate; last flagellomeres all with about $0.03 \mathrm{~mm}$ in length (Figs. 2 and 3); circumfila as in Figures 4 and 5. Frontoclypeus intensely setose. Labrum long-attenuate with two pairs of ventral setae. Labella hemispherical, each with some lateral setae and two pairs of short setae. Palpus with four setose segments: segment 1 globose, $0.02 \mathrm{~mm}$ in length in both sexes $(\mathrm{n}=4)$; segments $2-4$ cylindrical, segment 2 the widest one, and $0.03-0.04 \mathrm{~mm}$ in length in both sexes $(\mathrm{n}=6)$; segment 3 $0.03-0.045 \mathrm{~mm}$ in length in both sexes $(\mathrm{n}=6)$; segment 4 the longest, $0.04-0.06 \mathrm{~mm}$ in length $(\mathrm{n}=6)$.

Thorax: anepimeron with 7-12 setae; other pleural sclerites asetose; wing (Fig. 6): length (from arculus to apex): 1.1-1.4 $\mathrm{mm}(\mathrm{n}=9)$; tarsal claws bowed beyond midlength, and toothed; empodium reaching bend in claws (Fig. 7).

Abdomen: male (Fig. 8): tergites 1-7 rectangular, more sclerotized caudally, with complete row of caudal setae, two basal trichoid sensilla, and elsewhere with scales; tergite 8 not sclerotized with only two basal trichoid sensilla; sternite 2-5 


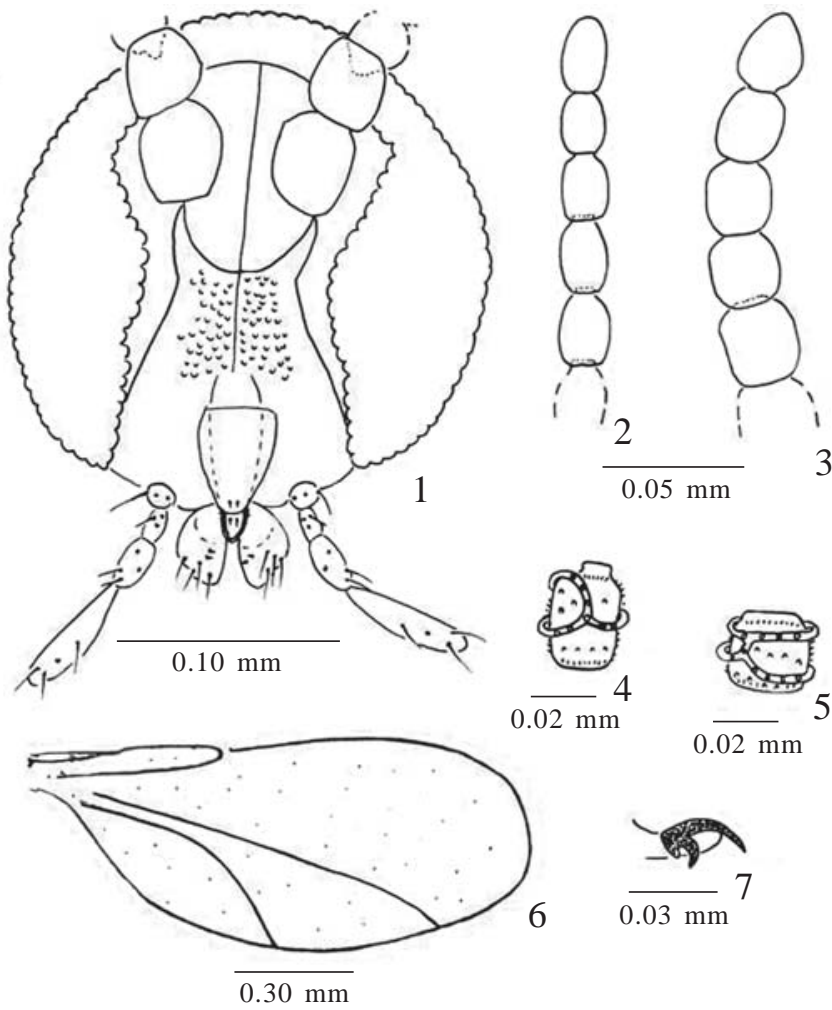

Figs. 1-7. Neolasioptera ramicola sp. nov. 1, male, head, frontal view; 2 , male last flagellomeres; 3 , female last flagellomeres; 4, male flagellomere 5; 5, female flagellomere 12; 6 , male wing; 7, male, tarsal claw and empodium of hindleg.

rectangular, more sclerotized caudally, with complete row of setae mesally and caudally, lateral setae, two basal trichoid sensilla, and elsewhere with scales; sternites 6-8 rectangular, more sclerotized caudally, with few mesal setae, some lateral setae, complete row of caudal setae, two basal trichoid sensilla, and elsewhere with scales. Male terminalia (Fig. 9): gonocoxite not splayed, about $0.10-0.12 \mathrm{~mm}$ in length, 2.4 times as long as wide, about 1.8-1.9 times as long as gonostylus and setose; gonostylus relatively short, widest at basal $1 / 2$, about 0.06 $0.05 \mathrm{~mm}$ in length, basally setulose and elsewhere with striae and some setae; cerci setose, with rounded margin; hypoproct simple, longer than cerci, and setose; parameres longer than hypoproct; aedeagus tapering gradually to apex, and with ounded margin. Female (Fig. 10): tergites 1-6 rectangular, with complete row of caudal setae, two basal trichoid sensilla, and elsewhere with scales; tergite 7 rectangular, with anterior and posterior margins slightly concave at middle, complete row of caudal setae, some lateral setae, two basal trichoid sensilla, and elsewhere with scales; tergite 8 variable in shape, as in Figures 11-13; sternites 2-6 rectangular, with complete row of setae mesally and caudally, two basal trichoid sensilla, and elsewhere with scales; sternite 7 rectangular, with setae more abundant mesally and caudally, two basal trichoid sensilla, and elsewhere with scales; sternite 8 not sclerotized. Ovipositor (Fig. 14) protrusible; cerci fused, elongate-ovoid, about 2.5 times as long as wide, and setose (Fig. 15).

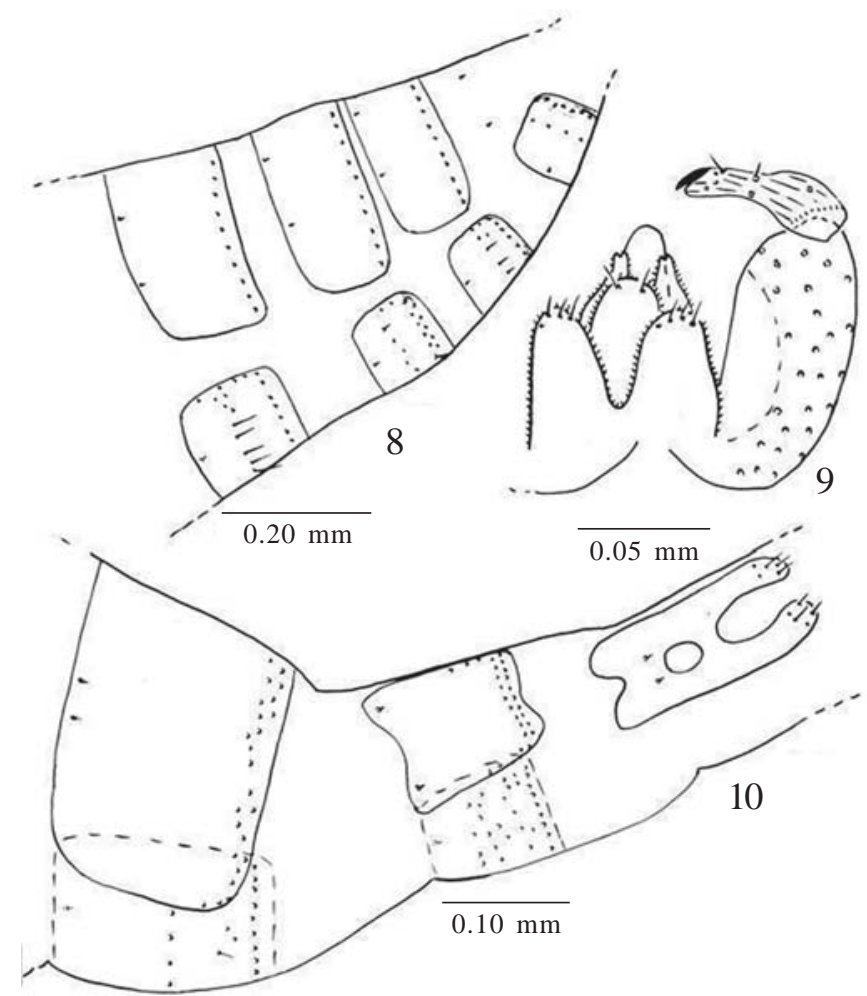

Figs. 8-10. Neolasioptera ramicola sp. nov. 8, male abdominal segments 5-8, dorsolateral view; 9, male terminalia, dorsal view; 10, female abdominal segments 6-8, dorsolateral view.
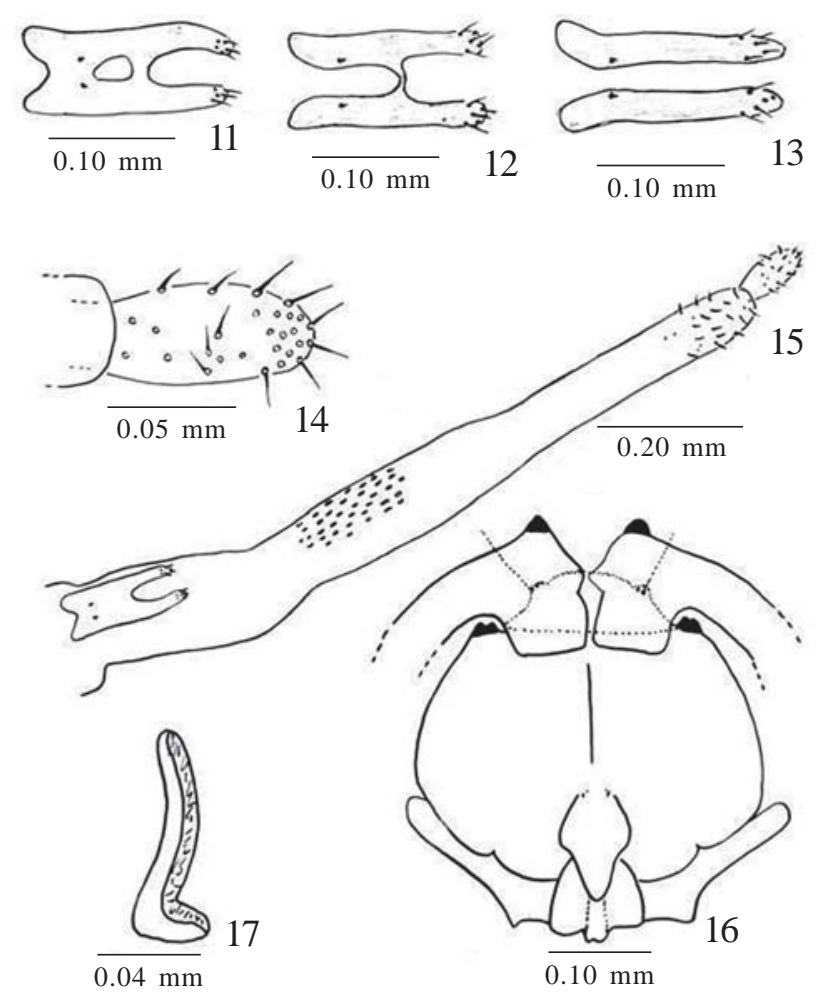

Figs. 11-17. Neolasioptera ramicola sp. nov. 11, female, tergite 8, ventral view; 12, same, another specimen; 13. same, another specimen; 14, ovipositor, dorsolateral view; 15, female fused cerci, dorsal view; 16. pupa, head, ventral view; 17. pupa, prothoracic spiracle. 

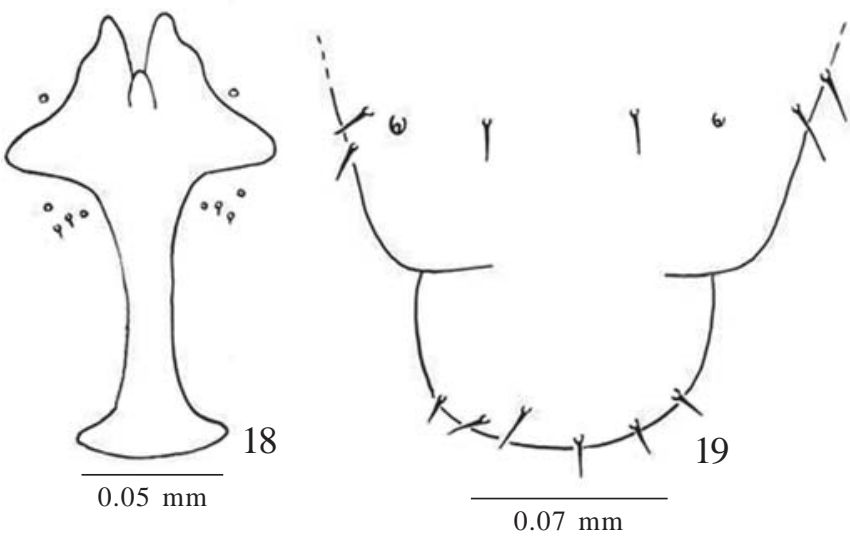

Figs. 18-19. Neolasioptera ramicola sp. n. 18, larva, prothoracic spatula, sternal and lateral papillae, ventral view; 19, larva, terminal segments, dorsal view.

Pupa. Length: 2.7-2.9 mm (n=3). Hed (Fig. 16): antennal horn triangular and short, $0.02 \mathrm{~mm}$ long $(\mathrm{n}=3)$, cephalic setae $0.08 \mathrm{~mm}$ long $(\mathrm{n}=3), 2$ pairs of lower facial papillae (one pair setose and the other asetose), lateral papillae absent. Upper cephalic margin thickened laterally. Thorax: prothoracic spiracle digitiform and short, $0.08 \mathrm{~mm}$ long (Fig. 17). Abdomen: tergites 2-8 with spinules, terminal segment rounded.

Larva. Length: 1.6-2.0 mm ( $\mathrm{n}=3)$. Body elongate and cylindrical. Integument rough. Spatula (Fig. 18) $0.15-0.20 \mathrm{~mm}$ in length $(n=3)$, widened anteriorly and with three apical teeth, the middle one conspicuously shorter than the others; four lateral papillae per side; terminal segment (Fig. 19), convex with three pairs of setose terminal papillae, all similar in length.

Gall (Fig. 20). Fusiform stem gall, with internal galleries. The galleries initially are yellow-orange, becoming red-brown with the growth of the larvae. A great number of galling larvae are found in the galleries. The width of the gallery is the width of the larva.

Remarks. This is the second species of Neolasioptera to be associated with Physalis. The other one, $N$. argentata (Brèthes, 1917) was described from Argentina and induces stem galls on Physalis viscosa and Physalis sp. (Brèthes 1917; Houard 1933; Gagné 1994; Gagné 2004). The description of $N$. argentata is incomplete. Nevertheless, some differences between them can be pointed out, such as: the number of flagellomeres ( $N$. argentata: 15 in male and 19 in female; $N$. ramicola: $12-13$ in male and 15-18 in female); the relative length of the flagellomeres ( $N$. argentata: flagellomeres progressively

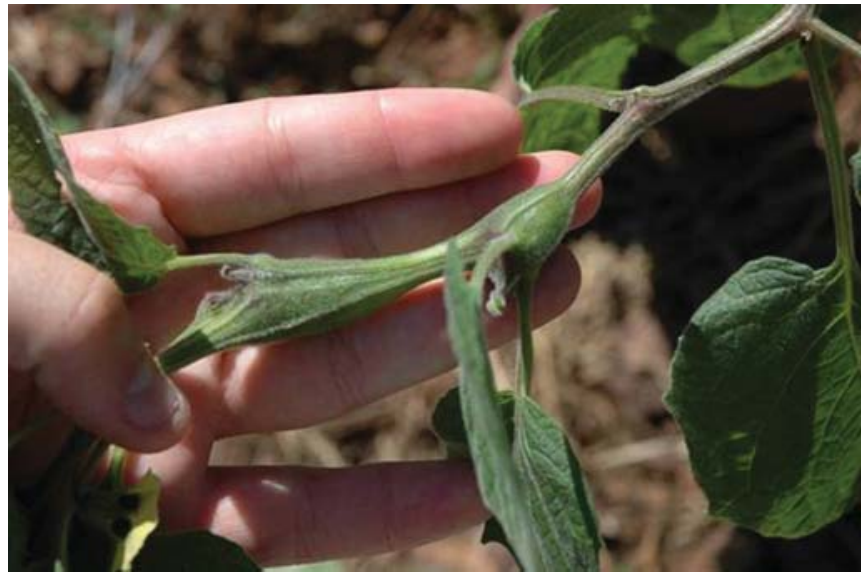

Fig. 20. Stem galls induced by Neolasioptera ramicola on Physalis angulata (Solanaceae), general aspect.

shortened; $N$. ramicola: last flagellomeres similar in length); and the number of segments of palpus (N. argentata: $2 ; N$. ramicola: 4$)$. The immature stages of $N$. argentata are unknown. This is the seventh species of Neolasioptera to be described from Brazil.

Material examined: Holotype: male. BRAZIL, Rio Grande do Sul: Bento Gonçalves, 19.IV.2007, M. Zart col. (MNRJ). Paratypes: same data as holotype, 4 males, 5 females, 3 larvae; same locality and collector: 20.IV.2007, 1 female; 10.V.2007, 3 larvae; same locality, 04.X.2007, same collector: 4 pupal exuviae and 2 pupae (MNRJ).

Etymology. The name ramicola means stem inhabitant.

Acknowledgements. We thank FAPERJ (Fundação de Amparo à Pesquisa do Estado do Rio de Janeiro, Proc. E-26/171.290/06) and CNPq (Conselho Nacional de Desenvolvimento Científico e Tecnológico, Proc. 472084/2007-0, 301197/2007-5 and 304851/20043) for financial support.

\section{REFERENCES}

Brèthes, J. 1917. Sur une cécidie de Physalis viscosa: description de la cécidie et de la Cécidomyie. Physis 3: 239-240.

Briguenti, A. F. \& C. M. Madeira. 2007. Physalis, uma alternativa para o fruticultor. Jornal da Fruta XV 187, Lages, SC, Brasil.

Gagné, R. J. 1994. The gall midges of the Neotropical region. Cornell University Press. XV +352 pp.

Gagné, R. J. 2004. A catalog of the Cecidomyiidae (Diptera) of the world. Memoirs of the Entomological Society of Washington 25, $408 \mathrm{pp}$.

Houard, C. 1933. Les Zoocécidies des Plantes de l’Amérique du Sud et de l'Amérique Centrale. Hermann \& Cie, Paris. 549 pp. 